\title{
Şark Medreselerinde Toplumsal Cinsiyet Anlayışı: Diyarbakır Seydaları Üzerinden Betimsel Bir Analiz*
}

\author{
ABDUSSAMET KAYA \\ Dicle Üniversitesi İlahiyat Fakültesi \\ abdusamet.kaya@dicle.edu.tr \\ https://orcid.org/0000-0003-1277-2713
}

\begin{abstract}
Öz
Medreseler, Türkiye'nin Doğu Anadolu ve Güneydoğu Anadolu bölgelerinde asırlardır geleneksel dinî düşüncenin merkezleri olarak faaliyette bulunmuş kurumlardır. Bu kurumlar, günümüzde resmi bir statüleri bulunmamasına karșın bölgedeki etki gücünü korumakta ve geniș bir toplumsal kesime hitap etmektedir. Bu kurumlarda temel dinî otorite, "seyda" olarak adlandırılan, saygı gören ve topluma bazı alanlarda yön veren kimselerdir. Seydaların din anlayışları ve dinle ilişkili belirli konulara yaklaşımları, bölge halkının ilgili konular bağlamındaki genel tutumunun tespitine de imkan tanımaktadır. $\mathrm{Bu}$ nedenle, bu çalışmada Seydalar örneklem zemini olarak belirlenmiştir. Çalışmanın üzerine kurulu olduğu ana tema ise, toplumsal cinsiyet ve din ilişkisidir. Çağdaş İslam düşüncesinde üzerinde en fazla tartışılan konulardan biri olan bu tema, din sosyolojisinin de temel ilgi alanlarındandır. Bu çalışmaya yansıyan hususlar, din sosyolojisi zaviyesinden ve Diyarbakır ilindeki bazı Seydalar üzerinden toplumsal cinsiyet ve din ilişkisini tespite yönelik bir araştırmanın bulgularıdır. Araștırmada verilerin toplanması sürecinde nitel bir araştırma yöntemi izlenmiş, bunların ortaya konulması ve sunulması noktasinda da betimsel bir üslup benimsenmiștir.
\end{abstract}

Anahtar Kelimeler: Din Sosyolojisi, Toplumsal Cinsiyet, Medrese, Seyda, Din Anlayıșı.

The Perception of Gender in the Madrasas of Eastern Turkey: A Descriptive Analysis through the Seydas of Diyarbakır

Abstract

Madrasahs located in Eastern and Southeastern Anatolia regions of Turkey have operated as centers of traditional religious thought for centuries. Although these institutions do not have an official status nowadays, they have maintained their influence in the region and have appealed to a wide social sector. The basic religious authority in these institutions are seydas who are respected and guide society in some fields. The religious understanding of Seydas and their approaches to certain issues related to religion allow us to determine the general attitude of the people in the context of related issues. Therefore, in this study, seydas are selected as a sample group. The main theme of the study is the relationship between gender and religion. This theme, which is one of the most debated issues in contemporary Islamic thought, is also one of the main interests of the 
sociology of religion. The points reflected in this study are the findings of a study focusing on the relationship between gender and religion through the seydas of Diyarbakır from the point of view of the sociology of religion. In the research, a qualitative research method was followed in the process of data collection and a descriptive technique was adopted in order to reveal the results and present them.

Keywords: Sociology of Religion, Gender, Madrasah, Seyda, Understanding of Religion.

\section{Giriş}

Toplumsal cinsiyet meselesi, modern dönemdeki din tartışmalarında başat konular arasında yer almaktadır. Müslüman toplumların modernleşme süreçlerine girmeleri ve özellikle kadının ev dışında ücretli çalışmaya başlaması, Müslümanların kadın konusundaki anlayışlarında ciddi kırılmalara neden olmuştur. Bu tartışmalar temelde kadının ontolojik değeri, eğitimi, erkeğe nispeten aile ve toplumsal hayattaki konumu, ücretli çalışması, kamuda yöneticiliği, kadına yönelik şiddet, toplumdaki namus anlayışı ve namus cinayetleri gibi konularda cereyan etmektedir.

Bütün geleneksel din anlayışlarında olduğu gibi Müslümanların din ve toplum anlayışları da dinin temeli kabul edilen klasik kaynaklar ve bunların dinî otoriteler tarafından ortaya konulmuş yorumları çerçevesinde şekillenmiştir. Ancak modernleşme süreçlerini biçimlendiren yeni paradigmalar, beraberinde yeni meşruiyet kaynakları ortaya çıkarmış ve geleneksel dinî otoritelerin belirleyici etkilerini daralmaya veya dönüşmeye maruz bırakmiştır.

Öte yandan Türkiye'de en yüksek siyasi karar mekanizmalarının, zaman zaman dinin "güncellenmesi" gerektiği yönündeki beyanları ve bazı dinî çevrelerin buna yönelik tepkileri, erken yaşta evlilikler, müftülere nikah yetkisinin verilmesi, halvet ve mahremiyet gibi konularda yaşanmakta olan tartışmalar, toplumsal cinsiyet ve din meselesini yeniden gündemin önemli bir konusu haline getirmiştir.

Bu çalışmanın temel problemini; yaşanmakta olan köklü değişim ve dönüşüm süreçlerinde, geleneksel dinî otoriteler olarak seydaların toplumsal cinsiyet anlayışlarının keyfiyeti oluşturmaktadır. Bu bağlamda, bu çalışmada hızlı bir toplumsal değişme sürecini yaşamakta olan Türkiye'de, geleneksel ve modern din anlayışları arasındaki gerilim kavşaklarından biri olan toplumsal cinsiyet konusunun, geleneksel dinî otoriteler olarak seydalar tarafından nasıl değerlendiriliği hususu betimsel olarak ortaya konulmaya çalışılmıştır. 


\section{Yöntem ve Kavramsal Çerçeve}

Bu çalışmanın metodolojik çatısı, nitel bir araştırma metodu olarak kurgulanmıştır. Sosyolojik çalışmalarda araştırma konusu, yöntemin belirlenmesine doğrudan etkide bulunur. Bu araștırmanın probleminin, bir anlayıșı kavramaya yönelik olması ve bunun da bir zihniyet çözümlemesini gerektirmesi, araştırma yönteminin belirlenmesinde temel etken olmuştur. Zira sözü edilen zihniyet çözümlemelerinin işlevsel bir çıtısı ancak uzun süreli gözlem ve derinlemesine görüşmelerle elde edilebilir.

Araştırmanın teorik çerçevesinin tespiti ve konunun geleneksel ve modern anlayışlar bağlamında ortaya çıkardığı gerilim noktalarının teşhisi için, toplumsal cinsiyet konusunun dinin temel kaynaklarında yer alış biçimi incelenmiş, geleneksel dinî eğitim kurumları olarak medreselerin söz konusu anlayışların yeniden üretilmesindeki rolü anlaşılmaya çalışılmıştır.

Bu çerçevede araştırmanın verileri 2014-2015 yıllarında Diyarbakır'da, yirmi seyda ile yapılan yarı yapılandırılmış görüşmelerden ve daha geniş bir sürece yayılan gözlemlerden elde edilmiştir. Görüşülen seydalar çoğunlukla Diyarbakır ve çevre medreselerde eğitim görmüş, orta düzey gelire sahip kimselerdir. Bunlardan biri yerel bir tarikatın şeyhi bir diğeri ise Türkiye'de yaygın bir tarikatın mürididir. Görüşmelerden elde edilen veriler bilgisayar ortamında temalandırılıp kodlanarak analiz edilmiştir. Seydalardan yapılan doğrudan alıntılardaki dilsel problemlere müdahale edilmemiş, seydaların isimleri kodlanarak ancak yaşları parantez içinde olduğu gibi verilmiştir. Bu araştırmada seçilen sosyolojik yöntemin paradigmatik yaklaşımı gereğince, ulaşılan sonuçlar ve yapılan değerlendirmeler, araştırmanın yapıldığı tarih ve seçilen evren ve örneklem ile sınırlıdır.

\subsection{Toplumsal Cinsiyet}

Toplumsal cinsiyet konusu, erkekler ve kadınlar arasındaki psikolojik, sosyal ve kültürel farklılıklara gönderme yapan ${ }^{1}$ ve kültürün hemen her alanı ile bir şekilde ilişkili olan bir konudur. Toplumsal cinsiyet ve din bağlamında kadın, geleneksel ve özellikle modern İslam düşüncesinin temel tartışma konularından biri olmuştur. Modern dönemde İslam dinine yöneltilen eleştirilerde toplumsal cinsiyet meselesi ağırlıklı bir konumda yer almış, bu eleştiriler karşısında Müslümanlar, gelenekçi ve modernist anla-

\footnotetext{
* Bu makale, yazarın "Medrese Kökenli İmamlar İle İlahiyat Fakültesi Mezunu İmamların Din Anlayışlarının Karşılaştırmalı Analizi (Diyarbakır Örneği)" başlıklı doktora tezinden (Ankara Üniversitesi, Ankara, 2017) üretilmiştir.

${ }^{1}$ Anhony Giddens ve Philip W. Sutton, Sosyolojide Temel Kavramlar, terc. Ali Esgin (Ankara: Phoenix Yayınları, 2016), s.185.
} 
yışları da kapsayan farklı yaklaşımlar ortaya koymuşlardır. ${ }^{2}$ Hatta çağdaş İslam düşüncesindeki birçok fikri eğilimin, kadın konusuna yaklaşımı üzerinden kendini konumlandırdığı söylenebilir.

\subsection{Seyda}

Seyda, (Doğu ve Güneydoğu Anadolu) Şark medreselerinde, dinî eğitimini tamamlayarak icazet almış ve medresede ders veren dinî otoritedir. Seydayı, geleneksel olduğu kadar, meşruiyetinin dinî-kitabî bilgiye vukufiyetine bağlı olması itibariyle bir bakıma yasal-ussal dinî otorite olarak tipleştirmek de mümkündür. Seydalık, ortalama 8-10 yıl süren ve yoğunlukla Arapça öğretimi merkezli bir medrese eğitiminden sonra icazetname alınarak ve bir medresede ders vererek kazanılan bir statüdür.

Seydaların geleneksel toplum yapısı içinde din gibi dominant bir kurumun önderleri olmaları ve toplumsal rollerinin işlevselliği, onlara yüksek bir statü kazandırmıştır. Geleneksel dinî hafızanın taşıyıcıları ve her türlü dinî etkinliğin yürütücüleri olarak seydaların yüksek toplumsal statüsü, modernleşme süreçlerinin çok yönlü etkileri ile birlikte aşınmaya uğramıştır. Öte yandan modern hayatın birçok pratik ve pragmatik gerekliliği seydaları, bazı geleneksel anlayışları yeniden değerlendirmeye ve çeşitli melez anlayışlar ortaya koymaya yöneltmektedir. Bu bağlamda seydaların toplumsal cinsiyet konusundaki anlayışlarının, onların genel olarak din anlayışları hakkında ipucu verebileceği düşünülebilir.

\section{Seydaların Toplumsal Cinsiyet Konusuna Yaklaşımları}

$\mathrm{Bu}$ çalışma özelinde seydaların konuya yaklaşımları; ontolojik açıdan kadının değeri, kadının eğitimi ve çalışma hayatı, kadına yönelik şiddet, namus ve namus cinayetleri şeklinde dört ana zeminde tespit edilmeye çalışılmıştır.

\subsection{Kadının Ontolojik Değerine Yaklaşımları}

İslam toplumlarında kadının dinî ve sosyal statüsünün Kur'an'da yer alan buyruklar veya Hz. Peygamber'in pratiklerinden ${ }^{3}$ ziyade, hadis rivayet-

\footnotetext{
2 Bu yaklaşımlar genel olarak dört bakış açısını yansıtmıștır: 1) Toplumsal cinsiyet bağlamında kadının olumsuz konumunun bizzat İslam dininin kendisinden kaynaklandığını savunan Batıcı aydınlar, 2) Kadının toplumsal konumunu makul gören gelenekçiler, 3) Dinî nasslara dayanarak ve onları te'vil ederek, kadının Batılı standartlarda özgürleștirilmesini savunan İslam modernistleri, 4) İslam'ın temel kaynaklarına dönerek, kadının konumunun yeniden düzenlenmesini öneren ıslahatçılar. Bkz. M. Said Şimşek, Günümüz Tefsir Problemleri (Konya: Esra Yayınları, 1995), ss.203-204.

${ }^{3} \mathrm{~Hz}$. Peygamber döneminde kadının dinî ve sosyal statüsü hakkında bkz. Rıza Savaş, Hz. Muhammed (sav) Devrinde Kadın (İstanbul: Ravza Yayınları, tsz.). Hadis rivayetlerinin, kadının toplumsal konumunun şekillenmesindeki etkileri konusunda ise bkz. Hidayet Şefkatli Tuksal, Kadın Karşıtı Söylemin İslam Geleneğindeki İzdüşümleri (Ankara: Kitâbiyât, 2000), s.51 vd.; Ali Osman Ateş, Hadis
} 
lerinin oluşturduğu söylem ile şekillendiği ifade edilebilir. ${ }^{4} \mathrm{Bu}$ söylemin gelişmesinde Yahudi ve Hıristiyan geleneğinden tevarüs edilen 'ayartıcı' Havva imgesinin ve Mezopotamya ataerkil kültürünün de etkisi olduğu şeklinde bir değerlendirme yapılabilir. ${ }^{5}$

Geleneksel toplum yapısı içinde kadının sosyal konumu, önemli bir kısmı İslam öncesi dönemlere dayanan dinselleştirilmiş gelenekler6 sayesinde meşrulaştırılmış ve yüzyıllarca değişime direnç göstermiştir. Özellikle kadının akıl ve din açısından eksik/yarım olduğu anlayışının bu şekilde tahkim edilmesi, kadına yönelik ayrımcılık, şiddet ve aşağılamanın önemli bir gerekçesini oluşturmuştur.

Geleneksel ve modern din anlayışlarının dinî ve sosyal konulardaki tavır alışlarında kadın, merkezî bir konumda yer almaktadır. Dolayısıyla kadına yönelik algılar, din anlayışının şekillenmesinde önemli bir ağırlığa sahiptir. Toplumsal cinsiyet anlayışları bağlamında kadının ontolojik değerine bakışlarının anlaşılması amacıyla seydalara; "Kadın erkek eşitliği hakkında neler düşünüyorsunuz?" "Kadının eksik yaratıldığı rivayetleri hakkında neler söylersiniz?" ve "er-ricālu kavvāmūne 'alä'n-nisā’i (4/en-Nisā’'34) ayetini nasıl anlıyorsunuz?" şeklinde sorular sorulmuştur.

Seydaların, kadınların ontolojik değeri veya dinen ve aklen eksik oldukları düşüncesi hakkındaki yaklaşımları monoblok bir söylem biçiminde değildir. Bu konuda seydaların düşüncelerinin, "kadın fizik, akıl ve din yönünden eksiktir" ve "kadınların fitratları erkeklerden farklıdır ama dinen ve aklen erkeklere göre eksik değildirler" şeklinde olduğu anlaşılmaktadır.

Bazı seydalara göre Allah, kendisine kul olmaları noktasında kadın ve erkek arasında bir ayırım yapmamıștır. Ancak kadın ve erkeği dünya hayatında icra edecekleri rollerine uygun imkan ve kabiliyetlerle yaratmıştır. Kadının asli rolleri annelik ve ev içi hizmetler olduğundan, ona bu rollerini yerine getirmesinde işlevsel olan fiziksel ve duygusal özellikler, erkeğe ise ailenin korunması ve iaşesinin teminindeki sorumluluğu gereği güç, dayanıklılık ve soğukkanlılık gibi özellikler verilmiştir. Bu haliyle iki cins arasında eşitlikten değil de adaletten söz edilebilir. Dolayısıyla kadın ve erkeğin

Temelli Kalıp Yargılarda Kadın (İstanbul: Beyan Yayınları, 2000), s.25 vd.; İbrahim Sarmış, Rivayet Kültürü ve Olumsuz Kadın Algısı (İstanbul: Düşün Yayınları, 2011).

${ }^{4}$ Bkz. Amine Vedûd-Muhsin, Kur'ân ve Kadın, terc. Nazife Şişman (İstanbul: İz Yayıncıllk, 2005).

${ }^{5}$ Bkz. Fatmagül Berktay, Tektanrılı Dinler Karşısında Kadın (İstanbul: Metis Yayınları, 2009), s.80 vd.; Hüseyin Hatemi, Kadının Çıııı̧ Yolu: İlâhî Hikmet'de Kadın (İstanbul: İşaret Yayınları, 1990), s.9; Mehmet Okuyan, “Kadına Yönelik Șiddete Kur'ân'ın Bakışı,” OMÜIFD 23 (2007), ss.93-134.

${ }^{6}$ Ateș, Hadis Temelli Kalıp Yargılarda Kadın, s.151; Riaz Hassan, Müslüman Zihinler, terc. Ergin Çenebaşı (İstanbul: Doğan Kitap, 2010), s.192. 
eşit olduğunu iddia etmek veya onları kendilerine verilen rolleri dışında tanımlamak, Allah'ın iradesine veya Sünnetullaha karşı çıkmak gibidir.

Kadın ve erkek eşitsizliğine vurgu yapan seydalar ise, kadının akıl ve dindarlık bakımından eksik olduğunu bildiren rivayetlerī șahịh kabul etmekte ve bu durumu makul bulmaktadırlar. Onlara göre kadınların muayyen hallerde namaz kılamayıp oruç tutamaması, cuma ve bayram namazlarına katılamamaları, cihada iștirak edememeleri gibi durumlar onları dindarlık bakımından erkeklere göre dezavantajlı kılmaktadır. Aklen eksik olmaları ise kadınların duygusal, dolayısıyla tutarsız veya fevri davranışlara yatkın yapılarından ve genel olarak dışarıdaki hayat hakkındaki bilgisizliklerinden kaynaklanmaktadır. Seydalara göre İslam hukukunda şahitlik konusunda iki kadının bir erkeğe denk tutulması, kadınların aklen zayıf olduklarını göstermektedir.

Bazı seydalar ise kadın ve erkeğin fitratlarının farklı olduğunu ve dolayısıyla sosyal hayatta geleneksel olarak tahsis edilmiş rol dağılımının veya şeriatın her iki cins hakkındaki hükümlerinin makul olduğunu kabul etmekle birlikte, kadınların aklen ve dinen eksik oldukları düşüncesine katılmamaktadırlar. Bu anlayıștaki seydalar, kadın karșıtı hadis rivayetlerini ya red veya te'vil etmektedirler. ${ }^{8}$ Onlara göre toplumsal cinsiyet konusunda feminist söylemler de ataerkil anlayışlar da kadın ve erkek cinsinin fıtri yapısını göz ardı etmektedirler.

Kendileriyle görüşülen seydaların tamamı, otorite ilişkileri bağlamında kadının erkeğe tabi olması gerektiğini düşünmektedirler. Onlara göre, Kur'an'da 4/en-Nisā' suresinin 34. ayetinde yer alan "er-ricālu kavvāmūne 'alā'n-nisā’i ..." ifadesi, erkeklerin kadınlar üzerinde hâkim ve idareci olduklarını bildirmektedir. Bu otorite ilișkisi Allah tarafından belirlenmiştir. ${ }^{9}$ Öte yandan kadınların zayıf fiziksel ve duygusal yapıları karşısında erkeklerin yöneticilik için gerekli olan şartları haiz olmaları söz konusu rol tahsisinin tutarlılığını göstermektedir.

\footnotetext{
${ }^{7}$ Muslim, Kitābu'l-Īmān 34 (no.79).

${ }^{8} \mathrm{Bu}$ anlayıștaki bazı seydalara göre kadının aklen ve dinen eksik olduğunu ifade eden hadis, kadının duygusallığını ve ibadetler konusunda onları teşvik etmeyi içermektedir.

9 Ulemanın evlilik ve aile hayatı konusundaki nassları erkek egemenliğine yormamaları, kadın açısından birçok sorunu beraberinde getirmiștir. Bu yorumlarla kadının evlilik ilișkisindeki rolü cinsellikten ibaret sayılmıș ve nikah da bir kölelik akdi gibi anlașılmıștır. Bkz. Mehmet Erdoğan, "Kadın Hakları Bağlamında Boşanma Sorunu," Rahmi Yaran ve Abdurrahman Dodurgalı (yay. haz.), İslam Düşüncesinde Yeni Arayışlar III (İstanbul: Rağbet Yayınları, 2000), ss.138-149. Bu anlayışlar paralelinde evliliğin kadının ezildiği bir kuruma dönüștüğü konusunda bkz. Vedûd-Muhsin, Kur'ân ve Kadın, s.153. Boşama yetkisinin erkeğe verilmiș olması nedeniyle, kocasından boșanmak isteyen kadınların irtidat etmek zorunda kaldığı konusunda bkz. Muhammed İkbal, İslam'da Dinî Düșüncenin Yeniden İnșâsı, terc. Rahim Acar (İstanbul: Timaș Yayınları, 2013), s.206.
} 
Geleneksel anlayış erkeği güç, idare etme ve kültür üretme gibi özellik ve rollerle tanımlarken, kadını ise zayıflık, itaat ve edilgenlikle özdeşleştirir. Her iki cinsiyete ilişkin bu algılar kadını, ev içi hizmetler ve anneliğe ilişkin rollere fiziksel ve psikolojik yatkınlığı ile; erkeği ise ev dışında ve daha çok kültür üretme/aktarma kabiliyeti ve iktidar kaynağı olması ile öne çıkarır. Seydaların büyük çoğunluğunun, kadın erkek eşitliği konusunda geleneksel cinsiyet anlayışını paylaştıkları anlaşılmaktadır. Bu anlayışa göre kadın, erkeğe oranla birçok yönden zayıf yaratılmıştır. Bu eksikliğine bağlı olarak kadın, hayatın pek çok alanında ikincil bir pozisyonda yer almalıdır. Bu anlayışa göre kadının ailede, siyasal ve kültürel alanlarda dominant roller üstlenmesi birçok olumsuzluğun temel nedenini oluşturur.

Kendisiyle görüşülen seydaların çoğu, kadının bazı özellikleri bakımından erkeğe kıyasla daha zayıf olmasını ontolojik bakımdan bir kötülük olarak görmemektedir. Ancak kadınların yaratılışlarından dolayı dindarlık ve akli melekeleri yönünden erkeklerden daha eksik olduğunu düşünmektedirler. Seydalar, kadın ve erkeklere, biyolojik ve ruhsal kabiliyetlerine göre dinî ve sosyal alanlarda farklı hak ve sorumlulukların verilmiş olmasını ilahi adaletin gereği olarak yorumlarlar. Seydaların kadına yönelik bu anlayışlarının onların, kadının sosyal hayattaki konumu hakkındaki düşünce ve tutumları üzerinde etkili olduğu söylenebilir.

\subsection{Kadının Eğitimi ve Ücretli Çalışmasına Yaklaşımları}

Kadının eğitimi ve çalışma hayatına katılması konusundaki toplumsal algının değişmesi, hızlı bir toplumsal değişme sürecini de beraberinde getirmiştir. Öyle ki kadının meslek/kamu hayatına girişi ve makineleşme, toplumsal değişmenin iki eşiği sayılmıştır. ${ }^{10}$ Müslüman toplumlarda kadının eğitimi, ev dışında ücretli olarak çalışması veya yönetici olması gibi konular, klasik ve modern dönemde ulemanın çokça tartıştığı alanlar olmuştur. Bu bakımdan kadınların kamusal alana çıkışı hakkındaki yaklaşımlar, toplumun kültüründe ve Ehl-i Sünnete mensup dinî otoritelerin edinilmiş düşünce ve davranışlarında oluşan değişimleri gözlemek için önemli bir kriter olarak görülebilir.

Araştırma kapsamında, kadının eğitim hakkı, ücretli çalışması ve kamuda yöneticiliği hakkındaki düşüncelerinin anlaşılması için seydalara; "Kadının eğitimi hakkındaki fikriniz nedir?", Kadın dilediği her alanda eğitim alabilmeli midir?”, "Kadının ev dışında ücretli olarak çalışması hakkında

\footnotetext{
${ }^{10}$ Jean-Paul Charney, İslâm Kültürü ve Toplumsal Ekonomik Değişim, terc. Adnan Bülent Baloğlu ve Osman Bilen (Ankara: TDV Yayınları, 1997), s.91.
} 
neler düşünüyorsunuz?" ve "Kadınlar kamu kurumlarında yönetici olabilirler mi?" şeklinde sorular sorulmuştur.

Kendisiyle görüşülen yirmi seydanın neredeyse tamamı İslam dininde ilim öğrenmenin kadın ve erkek için farz olduğunu ve bu konuda cinsiyete dayalı bir ayırımın yapılamayacağını ifade etmektedir. Ancak kadınların eğitiminin şartları, alanı, ortamı ve önemi konularında seydaların düşünceleri çeşitlilik göstermektedir. Çoğunlukla seydalar kadınların, dinin farz-ı ayn olan kısımlarında ve kadınlara hizmet vermek amacıyla tıp ve öğretmenlik gibi, farz-ı kifaye sayllan alanlarda eğitim görmeleri gerektiğini, diğer alanlarda ise buna ihtiyaç olmadığını düşünmektedirler. Bazı seydalara göre ise kadın hem dinî hem de pozitif bilimler konusunda eğitim alma hakkına sahiptir.

Seydalara göre kadın, farz ibadetlerle ilgili konularda eğitim almak için kocasından izin almak zorunda değildir. Ancak, çocukların yetiştirilmesi, ev hizmetlerinin yürütülmesi gibi kadının asli görevlerinin aksamaması veya ailenin huzurunun bozulmasının önüne geçilmesi gibi gerekçelerle, kadının diğer alanlardaki eğitimi kocasının iznine bağlıdır.

Seydalar, eğitim ortamının mahremiyet ölçülerine göre düzenlenmiş olması gerektiğini özellikle vurgulamakta ve karma eğitimi kabul edilemez olarak değerlendirmektedirler. Seydalara göre Batılı tarzda karma bir eğitim sistemi, İslam toplumunun ahlaki çöküşüne yol açmaktadır. Bu yaklaşım, din anlayışı olarak genel eğilimleri farklı da olsa görüşülen bütün seydalar tarafından paylaşılmaktadır.

Eğitim konusunda Kur'an'da kadın-erkek ayırımı yapılmamıştır. Bazı hadis rivayetlerinde ise kadının eğitim öğretimini kısıtlayan ifadeler yer almıștır. ${ }^{11}$ Modern İslam düşüncesinde kadının eğitimi, kadınlık rollerini daha bilinçli olarak gerçekleștirmesini temin etmesi amacıyla önemsenmiştir. ${ }^{12}$ Buna göre, yaratılışlarına uygun işlerde çalışmaları şartıyla kadınların yüksek eğitim almaları ve çeşitli alanlarda uzmanlaşmalarına olumlu yaklaşılmış ancak yine de kadının öncelikli görevinin annelik olduğu savunulmuştur. ${ }^{13}$

\footnotetext{
${ }^{11}$ Bkz. Ateș, Hadis Temelli Kalıp Yargılarda Kadın, ss.141-150.

12 Bkz. Mazharuddin Sıddıkî, İslâm Dünyasında Modernist Düşünce, terc. Murat Firat ve Göksel Korkmaz (İstanbul: Dergâh Yayınları, 1990), ss.219, 247; Orhan Atalay, 20. Yüzyıl Tefsir Akımı: İçtimâî Tefsir (İstanbul: Beyan Yayınları, 2004), s.232.

${ }^{13}$ İhsan Çapçıŏlu, Modernleșen Türkiye'de Din ve Toplum (Ankara: Otto Yayınları, 2011), s.187.
} 
Osmanlı devletinde kız öğrencilerin ortaöğretim kurumlarına alınması, 1862'de başlamıștır. ${ }^{14}$ Türkiye Cumhuriyeti döneminde ise modernleşme projesinin bir parçası olarak kadınların eğitimi zorunlu hale getirilmiş ancak dindar toplum kı çocuklarını okula göndermemiştir. Dindar/muhafazakar toplum kesimlerinde, 1950-60'lı yıllarda ilkokul, 70'li yıllarda ortaokul-lise ve ardından üniversiteye karşı olan bu direnç kırılmıştır.15 Son dönemlerde yapılan araştırmalar, Türkiye'de kız çocuklarının okutulmasına yönelik olumsuz tutumun oldukça azalmış olduğunu göstermiştir. ${ }^{16}$ Benzer bir durum Diyarbakır için de söz konusudur. ${ }^{17}$

Kadının eğitimi konusunda seydaların düşüncelerinin, Diyarbakır halkının yaklaşımları ile paralellik arz ettiği görülmektedir. Görüşülen seydaların, kadınların eğitimi bağlamında toplumdaki algı değişimini olumlu buldukları ancak eğitimin alan ve ortamı ile ilgili bazı çekincelerinin olduğu anlaşılmaktadır. Seydaların tamamına yakınının karma eğitim konusunda olumsuz bir tutum sergilemeleri bu bağlamda değerlendirilebilir.

Kadının ev dışında ücretli olarak çalışmasına karşı dinî referanslarla geliştirilen tutum, din ve toplumsal cinsiyet bağlamında kadının konumuna yönelik yaklaşımları anlama imkanı sağlar. Araştırmada bu beklenti ile seydaların, kadınların özel veya kamu sektöründe ücretli çalışması hakkındaki düşünce ve tutumları araştırılmıştır.

Seydaların kadının ev dışında çalışması konusunu, zaruret hali, çalışma ortamındaki mahremiyet koşulları, kadının annelik görevleri ve kocasının izni gibi konular bağlamında değerlendirdikleri anlaşılmaktadır. Bahsedilen etkenleri gözeterek yaptıkları değerlendirmeler temalaştırıldığında seydaların, kadınların ücretli çalışması hakkındaki düşüncelerinin, "kadın, ancak zaruret hali veya kocasının izni varsa çalışabilir" ve "kadın dinen uygun şartlarda çalışabilir" şeklinde iki anlayış halinde öbeklendiği görülmektedir.

Çoğunluk itibariyle seydalar, ekonomik olarak zaruret halinin söz konusu olmadığı hallerde kadının ev dışında ücretli olarak kamuda veya özel sektörde çalışmasını uygun bulmamaktadırlar. Bu anlayıştaki seydalara

\footnotetext{
${ }^{14}$ Niyazi Berkes, Türkiye'de Çağdaşlaşma (İstanbul: Yapı Kredi Yayınları, 2004), s.231.

15 İsmail Kara, Şeyhefendinin Rüyasındaki Türkiye (İstanbul: Dergâh Yayınları, 2011), s.214.

${ }^{16}$ Bkz. Halil Aydınalp, “Türkiye’de Dinî Yapı: Örnek Alanlar Üzerinden Bir Tasvir," Hayati Hökelekli (ed.), Dindarlık Olgusu (Bursa: KURAV Yayınları, 2006) içinde, ss.301-318.

17 Diyarbakır'da toplumun tamamına yakını kadınların farklı düzeylerde de olsa eğitim görmesi gerektiğini düşünmektedir. Bkz. Bayram Kahraman, “Diyarbakır'ın Toplumsal Yapısı ve Diyarbakır Halkının Toplumsal Kurumlara Bakışı" (yayınlanmamış doktora tezi, Sakarya Üniversitesi, Sakarya, 2014), s.81; Rüstem Erkan, Güneydoğu Anadolu Bölgesinin Sosyal Yapısı ve Değișme Eğilimleri (Ankara: Kalan Yayınları, 2005), s.309.
} 
göre, ailenin geçim sorumluluğu kocaya aittir. Kadının asli görevleri ise annelik ve ev içi hizmetler olduğundan, her koşulda kadının çalışması kocasının iznine tabidir. Bu yaklaşımları ile seydaların çoğunluğunun, kadının ücretli çalışması konusunda yaşadıkları toplumda yaygın olan olumlu tutu$\mathrm{mu}^{18}$ paylaşmadıkları anlaşılmaktadır.

Bazı seydalar da İslam dininde kadının çalışmasına engel oluşturan bir hüküm bulunmadığını, dolayısıyla mahremiyet ilkelerine riayet edildiği takdirde kadının çalışmasının dinî açıdan bir sakıncasının olmadığını düşünmektedirler. Bu seydalar, konuyu zaruret şartından ziyade, kadının çalışma ortamının dinen uygunluğu bakımından değerlendirmektedirler. Bir seydanın buna dair açıklaması şu şekildedir:

... Şartlar müsait olursa kadın çalışabilir, kadın ticaret edebilir... kadın da iş sahibi olabilir, mühendis olabilir, müteahhit olabilir. Her şeyi çalışma ortamına bağlıyorum. Günümüz şartları müsait değil. Kadınların gidip evlerde çalışması müsait değildir. Kurumlarda kadın erkek beraber çalışması İslam'a uygun bir şey değildir. Beraber çalışabilirler fakat onun odası ayrı olabilir, onun odası ayrı olabilir. İmkan sağlanırsa İslam'a göre yani çalışlır. Fakat o imkanlar yoktur diyorum. (A. Kaymak: 60)

Esasen İslam dini, gerek ailede gerekse toplumsal hayatta kadın ve erkek arasında bir iş bölümü veya kadınların hangi işlerde çalışıp çalışamayacağını bağlayıcı metinlerle belirlememiş, bu konudaki kararı örf ve âdete, fayda ve maslahata bırakmıștır. ${ }^{19}$ Nitekim Hz. Peygamber döneminde kadınların üretim ve ticaret hayatına aktif bir şekilde katıldıklarına dair veriler mevcuttur. ${ }^{20}$ Dinin temel kaynaklarındaki bu ilkelere karşın seydaların kadının çalışması konusunda çoğunlukla örfün daraltıcı anlayışını benimsedikleri anlaşılmaktadır.

Din bağlamında toplumsal cinsiyet anlayışlarında ayrışmalara yol açan bir konu da kadının kamuda idareci olup olamayacağı meselesidir. İslam’da, devlet başkanlığı veya hâkimlik gibi görevler dahil olmak üzere kadının kamu görevini yapmasını yasaklayan açık, kesin, bağlayıcı bir nassın olma-

\footnotetext{
${ }^{18}$ Kahraman'ın çalışmasında, Diyarbakır halkının \% 62'sinin kadının gelir getiren bir işte çalışmasına olumlu yaklaștığı gösterilmiștir. Bkz. Kahraman, “Diyarbakır'ın Toplumsal Yapısı ve Diyarbakır Halkının Toplumsal Kurumlara Bakışı," s.103.

${ }^{19}$ Hayreddin Karaman, İslam'ın Işı̆̆ında Günün Meseleleri (İstanbul: Nesil Yayınları, 1992), c.3, ss.303, 311-314.

${ }^{20}$ Savaş, Hz. Muhammed (sav) Devrinde Kadın, ss.223-235; Mustafa Baktır, "İslam'da Kadının Çalışma Şartları," İsmail Kurt ve Seyit Ali Tüz (yay. haz.), Sosyal Hayatta Kadın (İstanbul: Ensar Neşriyat, 2005) içinde, ss.120-148.
} 
dığı belirtilmektedir. ${ }^{21}$ Ancak İslam uleması, Kur'an'dan, "erkekler kadınlar üzerinde idarecidirler"22 ve "(ey Peygamber hanımları) evlerinizde vakarla oturun"23 ayetleri veya "kadının aklının ve dininin eksik olduğu"24 ve "devlet başkanlığı işlerini bir kadının eline veren millet iflah olmaz"25 türünden hadis rivayetlerinin yanında kadının biyolojik ve ruhsal yapısını delil sayarak $^{26}$ onun kamuda idareci olamayacağına hükmetmişlerdir. ${ }^{27}$ Oysa tarihsel ve güncel pratiklere bakıldığında, İslam toplumlarında kadınların devlet başkanlı̆ ${ }^{28}$ ve ordu komutanlığ ${ }^{29}$ gibi yönetici pozisyonlarda yer aldıklarını görmek mümkündür.

Araştırma kapsamında, kadının kamusal alanın her kademesinde yönetici olup olamayacağı konusunda düşüncelerinin anlaşılması ve bu konudaki yaklaşımlarının karşılaştırılması amacıyla seydalara; "Kadınlar kamu kurumlarında yönetici olabilir mi?" şeklinde bir soru yöneltilmiş ve bazı sondaj sorularla bu konu hakkındaki yaklaşımlarının ayrıntıları anlaşılmaya çalışılmıştır. Kadınların kamusal alanda yönetici olması konusunda seydaların düşüncelerinin, "Kadınlar idareci olabilir ama devlet başkanı olamaz" ve "Kadınlar erkeklere yöneticilik yapamaz" şeklinde temalaştığı anlaşılmaktadir.

Araştırmanın örneklemini oluşturan seydaların çoğunluğu kadının, bürokratik organizasyon içinde, cumhurbaşkanlığı (devlet başkanlığı) makamı haricindeki diğer kademelerde yönetici olmasını yadsımamaktadır. Bazı seydalar ise kadınların devlet başkanlığına ek olarak kadılık veya hâkimlik de yapamayacaklarını düşünmektedirler. Bu anlayıștaki seydaların, kadının devlet başkanlığını, "Devlet idaresini kadınlara bırakan bir topluluk iflah olmaz" anlamındaki hadis rivayeti dolayısıyla, hâkimlik/kadılık görevini ise mezheplerin içtihatlarını gerekçe göstererek uygun bulmadıkları, 4/en-

\footnotetext{
${ }^{21}$ Hayreddin Karaman, "Kadının Şahitliği, Örtünmesi ve Kamu Görevi," İslâmî Araștırmalar 5:4 (1991), ss.284-291; Nejla Akkaya, "İslâm Hukukunda Kadının Siyasi Hakları," İslâmî Araştırmalar 5:4 (1991), ss.236-250.

22 4/en-Nisā':34.

23 33/el-Ahzāb:33.

${ }^{24}$ Muslim, Kitābu'l-Īmān, 34 (no.79).

${ }^{25}$ Ahmed b. Ḥanbel, el-Musned, c.5, s.43. Bu rivayetin tarihsel pratik açısından eleștirisi hakkında bkz. Mehmet Azimli, "Kadınların Yöneticiliği Konusundaki Rivayete Tarihsel Bağlamda Eleștirel Bir Yaklaşım," İslâmî Araștırmalar 15:3 (2002), ss.417-422.

${ }^{26}$ Akkaya, "İslâm Hukukunda Kadının Siyasi Hakları," ss.236-250; Mustafa Öztürk, Cahiliyeden Islamiyet'e Kadın (Ankara: Ankara Okulu Yayınları, 2012), s.108.

${ }^{27}$ Bkz. Hayreddin Karaman, İslam'da Kadın ve Aile (İstanbul: Ensar Neşriyat, 1993), s.98.

${ }^{28}$ Akkaya, "İslâm Hukukunda Kadının Siyasi Hakları," ss.236-250; Ali Merad, Çağdaş İslam, terc. Cüneyt Akalın (İstanbul: İletişim Yayınları, tsz.), ss.83-84.

${ }^{29}$ Mehmet Azimli, Siyeri Farklı Okumak: Medine Yılları (Ankara: Ankara Okulu Yayınları, 2009), c.2, ss.320-323.
} 
Nisā’ suresinin 34. ayetinde geçen, "Erkekler, kadınlar üzerinde idarecidirler...” ifadesindeki idareciliği ise her alandaki mutlak bir yöneticilik olarak görmedikleri anlaşılmaktadır.

Seydaların önemli bir kısmı kadının kamusal alanın herhangi bir kademesinde, erkeklere yönetici olmasını dinî açıdan doğru bulmamaktadırlar. $\mathrm{Bu}$ anlayışı paylaşan seydalar söz konusu yaklaşımlarını yukarıda verilen ayet ve hadislere dayandırmaktadırlar. Kadının toplumda söz sahibi olmasının, toplumun ifsadına ve çöküşüne neden olacağını düşünen bu seydalardan birine göre kadının yönetici olması kıyamet alametlerinden biridir:

... [kadının yönetici olması] dinimizin uyardı̆̆ı âhir zamanda olacağını haber verdiği alametlerin birisidir yani. ... Yani bir kadın[ın] yönetim işini üstlenmiş [olduğu] kavim iflah olmaz. Hadis-i şerifte geçiyor. Yani muhtarından tut şeyine kadar. Kadının yeri değildir bir kere. Olması caiz değildir ama maalesef vakıada vardır... Bunu bir kıyamet alameti olarak görüyorum. (S. Artaş: 35$)$

İnsanlar aile gibi bazı kurumlar hakkında daha muhafazakar iken, ekonomi gibi bazı kurumlar konusunda genellikle oportünisttirler. Bu bağlamda birer İslam hukuk otoritesi/fakihi olarak seydalar, toplumsal cinsiyet ilişkileri alanında bazı konularda konjonktürel şartların baskısı ve toplumun beklentilerine bağlı olarak müsamahakar bir tutum sergilerken diğer bazı durumlarda ise daha katı bir yaklaşıma sahip olabilmektedirler. $\mathrm{Bu}$ tutumları ile dinî hayatın bazı alanlarında temel prensiplerin dıșına çıkarken bazı alanlarda daha katı uygulamalara giderek 'dinin korunduğu' düşüncesinin var olmasını sağlarlar. ${ }^{30}$ Kadınların yönetici olmaları konusunda seydaların nispeten ılımlı tutumları da bu bağlamda değerlendirilmelidir.

Toplumsal değişme kuramları, değişim süreçlerinde cemaat ve cemiyet tipi toplumsal yapıları dikotomik bir şekilde kurgular ve bu kurguda geleneğin modernlikle birlikte var olamayacağı düşünülür. ${ }^{31} \mathrm{Bu}$ yaklaşımlarda geleneksellik ve modernlik arasındaki ara formlar göz ardı edilir. ${ }^{32}$ Oysa günümüz toplumlarında, tarihsel olarak söylemlerin birbirini izlediği düzenin yerini, tarihsel bilincin tüm düzeylerinin eşzamanlılığının aldığı bir dönem yaşanmaktadır. ${ }^{33}$ Başka bir ifade ile geleneksel ile modern olan arasında süreklilikler vardır ve bunlar birbirinden tamamen ayrı parçalar değil-

\footnotetext{
${ }^{30}$ Vejdi Bilgin, Fakih ve Toplum: Osmanlı'da Sosyal Yapı ve Flkıh (İstanbul: İz Yayıncılık, 2003), ss.8182.

${ }^{31}$ Mehmet Aysoy, Gelenek Sonrası Toplum Üzerine (İstanbul: Açı Kitaplar, 2003), ss.24-25.

32 Funda Gençoğlu Onbaşı, "Geleneksel ve Modern: Sınırlar ve Geçirgenlikler Üzerine," Doğu Batı 7:25 (2003), ss.83-98.

${ }^{33}$ Daryush Shayegan, Melez Bilinç, terc. Haldun Bayrı (İstanbul: Metis Yayınları, 2014), ss.25-26.
} 
dirler. ${ }^{34} \mathrm{Bu}$ bağlamda Türkiye'de özellikle 1980 'lerden itibaren yaşanan süreçlerde ortaya çıkan kapitalist İslamcı, milliyetçi sosyalist, sosyalist dindar ${ }^{35}$ vb. karışım kimlikler veya Müslüman aktörlerin, bir yandan İslam’a dair geleneksel yorumlara ve hükümlere mesafeli dururken, bir yandan da asimilasyoncu modernliği reddetmeleri, ${ }^{36}$ günümüzde artık dinî kimlikleri homojen bir görünüm içinde tanımlamanın mümkün olmadığını ${ }^{37}$ göstermektedir. Seydaların bahsedilen tutumlarındaki, geleneksel ve modern anlayışların iç içe geçmişliği ile oluşan melez desenlerin ortaya çıkardığı tablo, geleneksel ve modern anlayışların her zaman bir çatışma içerisinde bulunduğudüşüncesinin yersiz olduğu ${ }^{38}$ şeklindeki sosyolojik tespiti desteklemektedir.

\subsection{Kadına Yönelik Şiddete Yaklaşımları}

Kadına yönelik aile içi şiddet, yaygınlığı, yoğunluğu ve türleri değişmekle beraber, bütün toplumlarda var olmuş ve var olmaya devam eden bir olgudur. ${ }^{39}$ Bireysel ve toplumsal hayatta, tutum ve değer oluşturma konusundaki otoritelerden olan din adamları, dinin temel kaynakları ve devralınan kültürel değerleri yorumlama biçimleri ile toplumsal cinsiyet anlayışı ve bu bağlamda kadına yönelik tutum ve uygulamalar üzerinde -geleneksel toplumlarda daha fazla olmak üzere- önemli roller icra ederler. ${ }^{40}$

Araştırmada kadına yönelik fiziksel şiddete ilişkin düşüncelerinin anlaşılması için seydalara; "Kadınların dövülmesi hakkında ne düşünüyorsunuz?" șeklinde bir soru yöneltilmiştir. Bu konuda seydalardan alınan cevaplardan, onların tamamına yakınının kadının, kocası tarafından terbiye amacıyla ve belirli ölçüler dahilinde dövülebileceği düşüncesinde oldukları anlaşılmaktadır. Seydalara göre kadının dövülmesi dinî açıdan hoş karşılan-

\footnotetext{
${ }^{34}$ Anthony Giddens, Modernliğin Sonuçları, terc. Ersin Kuşdil (İstanbul: Ayrıntı Yayınları, 2014), s.13; Beylü Dikeçligil, "Kültür Kavramının Analizi veya Sosyo-Kültürel Gerçekliğin Yapısı Üzerine Bir İnceleme," Köksal Alver ve Necmettin Doğan (ed.), Kültür Sosyolojisi (Ankara: Hece Yayınları, 2013) içinde, ss.133-150.

${ }^{35}$ Hayrettin Oğuz, "Postmodern Bir Süreçte, Postmodern Bir Darbe ve Postmodern İslamcıllk," Gelenek ve Modernlik Arasında İslâmcllık (İstanbul: Umran, 2013) içinde, ss.261-268.

36 Bkz. Nilüfer Göle, Seküler ve Dinsel: Aşınan Sinırlar, terc. Erkan Ünal (İstanbul: Metis Yayınları, 2012), s.67.

${ }^{37}$ Asım Yapıcı ve Münir Yıldırım, "Küreselleșme Sürecinin Dinî Kimliklere Etkisi: Sosyal Psikolojik Bir Değerlendirme," Dinî Araştırmalar 6:17 (2003), ss.117-138.

38 Joseph R. Gusfield, "Toplumsal Değişim Araştırmalarında Yersiz Kutuplaşma: Gelenek ve Modernite," terc. Bilal Canatan, Muhafazakar Düşünce 1:3 (2005), ss.55-72.

392009 yılında Türkiye genelinde yapılan bir araștırmaya göre bölgelere göre farklılașmakla birlikte, kadınlarda şiddete maruz kalma oranı \% 39 olarak tespit edilmiștir. Bkz. Henrica A. F. M. Jansen ve diğerleri, Türkiye'de Kadına Yönelik Aile İçi Şiddet (Ankara: T.C. Başbakanlık Kadının Statüsü Genel Müdürlügü, 2009) içinde, s.46.

${ }^{40}$ Esra Aslan, "Din ve Şiddet Ekseninde Kadın Cinayetleri," Salih Öz ve Recep Vardi (ed.), Günümüz İslam Toplumları ve Problemleri Sempozyumu (İstanbul: Akademi Titiz Yayınları, 2015), ss.35-60.
} 
mamış, Hz. Peygamber'in kendisi kadını dövmemiş, bu fiili yapanları da tasvip etmemiştir. Bununla birlikte bazı hallerde son çare olarak kadının dövülmesine ruhsat/izin verilmiștir. ${ }^{41}$

Seydalar kadının, sadece naşize olduğu durumlarda dövülebileceğini düşünmektedirler. Kadının nüşûzunu ${ }^{42}$ ise erkeğin haklarını ihmal etmek, eve onun istemediği kimseleri almak, erkekten izinsiz evden çıkmak veya onun istemediği yerlere gitmek, gayr-ı meşru şeyler yapmak, kocayı rahatsız etmek, kocaya saygısızlık veya itaatsizlik etmek, kocanın yatağına girmemek veya yatağa çağırıldığı zaman icabet etmemek, küsmek, evi terk etmek, evdeki huzuru bozmak, kocanın malını korumamak, ırz ve namusuna dikkat etmemek, ahlaksızlık yapmak gibi tutum ve davranışlar olarak anlamaktadırlar.

Seydalara göre kadının nüşûzu/serkeşliği durumunda koca, Kur’an'da yer aldığı şekli ile kadına nasihatin ve onunla yatağını ayırmanın sonuç vermediği durumlarda son çare olarak kadını dövebilir. Fakat bu dövmenin bazı sınırları vardır. Örneğin kadının yüzüne vurulmamalı ya da darp işi kadını yaralayacak şekilde olmamalıdır. Bir seyda kadının kocası tarafından dövülme gerekçelerini ve șeklini șu ifadelerle dile getirmektedir:

... Nüşûz; yani kadın erkeği huzursuz ediyor, erkeği terk ediyor, erkeğin yapılması gereken ihtiyaçlarını vermiyor, isteğini yerine getirmiyor. Yani kadın ona darılmış. Zaten adam kadınla, kadınlık vazifesini yerine getirmesi için evleniyor... Allah-u Teâlâ diyor ona önce nasihat edin. Nasihatla yola gelmezse onu vurun [dövün]. Vurmak, kırmak, yaralamak manasında da değildir. Terbiye alabilmek için veya meseleyi anlayabilmek için. Onun için bir iki tokadın zararı yoktur. Bütün müfessirler öyle tefsir ediyorlar... 0 vurma da, aralarında bir irtibat oluyor. (i. Ezerkan: 70)

Görüşülen seydalardan birkaçı, kadının dövülmesini doğru bulmadıklarını ifade etmektedir. Bu seydalara göre Müslümanlar, Kur'an'ın bu konudaki ruhsatını istismar etmektedirler. Dolayısıyla Kur'an'ın ilgili ayeti te'vil edilerek kadına yönelik şiddetin kapısı kapatılmalı ve bu konuda Hz. Pey-

\footnotetext{
41 İslam geleneğinde bu konudaki yaygın kanaat, nasihat ve yatağın ayrılmasının sonuç vermediği durumlarda, ailenin bütünlüğünün korunması amacıyla kadının dövülmesine ruhsat olarak verildiğ șeklindedir. Bkz. Abdurrahman Ateș, Kur'an'a Göre Dinde Zorlama ve Siddet Sorunu (İstanbul: Beyan Yayınları, 2002), ss.304-305; Talip Özdeș, "İslam Açısından Kadının Konumu ve Kadına Yönelik Şiddetin Değerlendirilmesi," Eskiyeni 12 (2009), ss.68-76.

${ }^{42}$ Kadının dövülmesine illet olarak gösterilen nuşūz kavramı Kur'an'da 4/en-Nisā’':34'te geçmektedir. İlk dönem müfessirlerinin bu kavramı, kadının kocasına isyan etmesi, kocasıyla cinsel ilișkiden imtina etmesi gibi anlamlarla tefsir ettikleri kaydedilmiștir. Bkz. Elmalılı M. Hamdi Yazır, Hak Dini Kur'an Dili (İstanbul: Zehraveyn Yayınları, tsz.), c.2, s.558.
} 
gamber'in, eşlerine davranış biçimi örnek alınmalıdır. Bu anlayışı benimseyen bir seyda düşüncelerini şöyle ifade etmektedir:

... Kadının dövülmesi doğru değildir. Evet, ayette vardır. Hafifçe, yaralamadan dövün. Bizimkilerde, Kürt ve Türk ataerkil bir millettir. Onlar da onu düşünmeden eline ne geçerse tap rap döverler biliyor musun? Onun için bunun kapısını açmak doğru değildir. Peygamberimiz (sav), bu ayette dövün olduğu halde, Peygamberimiz hiçbir zaman kadınları dövmemiştir. Uygulama önemlidir. Ve hadiste buyuruyor: "hıyaruhum hıyaruhum li'n-nisai". Onların en iyileri kadınlara en iyi davranandır. Kadını dövmek yanlıştır. Ama feministler o hale getirdiler ki bu sefer kadın erkeği dövüyor. Bir denge kurmak lazım. Kadına hak verilirken, artık karma karışık olmuş. İslam'da dövme yoktur. Kim yapıyorsa yanlış yapıyor. Yani İslam'da, bu konuda adalet, ahlâk, iyi geçinme vardır... (K. İslamoğlu: 48)

Seydaların tamamına yakınının, kocanın, 'aile huzurunu bozduğu' veya 'kendisine itaat etmediği' durumlarda karısına, 'terbiye amaçlı' fiziksel şiddet uygulamasının dinî açıdan bir sakıncasının olmadığı düşüncesinde oldukları anlaşılmaktadır. Kadının itaatini seydalar, çoğunlukla cinsel bağlamlarla değerlendirmektedirler. ${ }^{43} \mathrm{Bu}$ anlayıştaki seydalar, kadınların akıl yönünden eksik olduğunu, bu yönleri ile çocuklara benzediklerini ve çocuklarda olduğu gibi, terbiye amaçlı ve ölçülü olmak kaydıyla, kadına fiziksel şiddet uygulanmasının normal ve 'gerekli' olduğunu düşünmektedirler.

Seydaların, kocanın karısına fiziksel şiddet uygulayabileceği düşüncesi temelde kaynağını 4/en-Nisā’ suresinin 34. ayetinin literal okunuşu ile yapılan tefsirlerinden ve fukahanın yorumlarından almaktadır. Seydalar söz konusu ayette geçen, "va-'dribūhunne (ve onları dövün)" ifadesinin, bazı çağdaş yorumcular tarafından "onları geçici olarak evden uzaklaştırın", "bulundukları yerden başka bir yere gönderin",44 "nasihate ve yatakta ayrı olma uygulamasına devam edin" 45 şeklinde açıklanmasının Kur'an'ın geleneksel yorumuna aykırı olduğunu düşünmektedirler.

\footnotetext{
${ }^{43}$ Seydaların, kadının cinsel konularda erkeğe itaati bu şekilde öncelemeleri fikhi temellere dayanmaktadır. Zira klasik fikıh kitaplarında cinsellik, evlilik akdinin en önemli unsuru kabul edilmiştir. Bu kaynaklarda, kadın ile erkek arasında yapılan nikah akdinin kadına yüklediği en önemli sorumluluk, erkeğin cinsel taleplerine cevap vermesi olarak hükme bağlanmıștır. Bkz. Erdoğan, "Kadın Hakları Bağlamında Boşanma Sorunu," ss.138-149; Okuyan, "Kadına Yönelik Şiddete Kur'an'ın Bakışı," ss.93-134.

${ }^{44}$ Benzer yorumlar için, Bayraktar Bayrakl, Edip Yüksel, Mustafa İslamoğlu ve Yaşar Nuri Öztürk'ün Kur'an meallerine bakılabilir.

45 Okuyan, “Kadına Yönelik Şiddete Kur’an'ın Bakışı," ss.93-134.
} 
Seydaların yetiştikleri sosyo-kültürel çevrede erkek egemenliğine dayalı bir toplumsal cinsiyet anlayışı egemendir. ${ }^{46} \mathrm{Bu}$ ataerkil toplum yapısı içinde bir kocanın karısına fiziksel şiddet uygulamasının geniş çapta din adına haklı görülmesi ${ }^{47}$ ve kadına bu konuda itiraz hakkı tanınmaması, ${ }^{48}$ kadınların da çeşitli gerekçelerle kendilerine yönelen bu şiddeti meşru görmeleri ${ }^{49}$ gibi nedenlerin seyda ve hocaların, kadınlara yönelik şiddet konusunda geleneksel ataerkil dinî yorumları benimsemelerine sosyal bir alt yapı sağladığı söylenebilir. Kur'an'da kadının erkeğe itaat etmesini isteyen herhangi bir buyruk yer almadığ ${ }^{50}$ ayrıca kadının dövülmesine mesnet kabul edilen nüşûz kavramının her iki cins için kullanılmış olduğu ${ }^{51}$ ve itaatsizlik değil, aldatmay ${ }^{52}$ ifade ettiği șeklindeki yorumlara rağmen, bu kavramın anlamının sadece kadına ve onun erkeğe itaatsizliğine hasredilmiş olması da erkek egemen kültürün Kur'an yorumları konusundaki cinsiyetçi anlayışını örneklediği şeklinde değerlendirilebilir.

\subsection{Namus ve Namus Cinayetlerine Yaklaşımları}

Kadına yönelik şiddetin en ağır biçimini, toplumun namus algısına bağlı olarak işlenen namus cinayetleri oluşturmaktadır. Kadının cinsel safiyetinin korunmasını bir değer olarak kabul eden, bunun için çeşitli normlar belirleyen ve bu normların ihlali durumunda belirli yaptırımlar uygulayan din, temelini çoğunlukla törelerden alan namus cinayetlerinin meşrulaştırılmasında, yardımcı bir unsur olarak kullanılabilmektedir. ${ }^{53}$

Kadınlara yönelik şiddet eylemlerinin en belirgin nedeni, toplumda kabul gören genel ahlâk ve namus anlayışıdır. ${ }^{54}$ Günümüzde de varlığını sür-

\footnotetext{
${ }^{46}$ Seydaların yetiştiği kültürel çevrede kadının konumu hakkında bkz. Mehmet Yalar, "Seyda, Mela ve Feqilerin Bölgenin Dini ve Kültürel Hayatındaki Yeri," Fikret Gedikli (ed.), Medrese Geleneği ve Modernleşme Sürecinde Medreseler (Muş: M. Ş. Ü. Yayınları, 2013) içinde, c.1, ss.459-470. Türkiye'de kadına yönelik şiddetin en yoğun olduğu bölgeler, Doğu ve Orta Anadolu ile birlikte Güneydoğu Anadolu bölgesidir. Bkz. Jansen ve diğerleri, Türkiye'de Kadına Yönelik Şiddet Raporu, s.47.

47 Rüstem Erkan ve Faruk Bozgöz, "Kadına Yönelik Şiddetin Sosyo-Ekonomik, Dinsel ve Kültürel Boyutları: Diyarbakır Örneği," EKEV Akademi Dergisi 8:18 (2004), ss.219-242.

${ }^{48}$ Hassan, Müslüman Zihinler, s.192.,

${ }^{49}$ Ceyda Alpago, "Kadına Yönelik Şiddet ve Kadın Sı̆̆ınma Evleri Olgusu" (yayınlanmamıș yüksek lisans tezi, İstanbul Üniversitesi, İstanbul, 2006), ss.34-35.

${ }^{50}$ Vedûd-Muhsin, Kur'ân ve Kadın, s.120.

${ }^{51}$ Vedûd-Muhsin, Kur'ân ve Kadın, s.117.

52 Muhammed Hamidullah, Aziz Kur'ân: Çeviri ve Açılama, terc. Abdülaziz Hatip ve Mahmut Kanık (İstanbul: Beyan Yayınları, 2003), s.246 (4/en-Nisā’:128'in dipnotu).

${ }^{53}$ Esra Aslan, "Töre Cinayetleri: Diyarbakır'da Göç Sonrası Töre" (yayınlanmamış yüksek lisans tezi, Dicle Üniversitesi, Diyarbakır, 2007), ss.63-72.

${ }^{54}$ Bkz. Birleşmiş Milletler CEDAW Komitesine Sunulmak Üzere Hazırlanan İkinci ve Üçüncü Birleştirilmiş Periyodik Türkiye Raporu, Ankara, 2003. https://www.tbmm.gov.tr/komisyon/kefe /belge/uluslararasibelgeler/ayrimcilik/CEDAW/ulke_raporlari/CEDAW\%20Komitesi'ne\%20verile
} 
düren bu anlayışta ırz, namus, iffet gibi ahlaki değerler kadının hanesine kodlanmıştır. Bu kodlama gereği söz konusu değerlerin korunması kadına, kadının bekçiliği de erkeğe ait görülmüştür. ${ }^{55}$ Dolayısıyla kadınlar bu sorumluluklarını hassasiyetle yerine getirmediklerinde erkekler tarafından şiddetle cezalandırılmaktadır.

Araştırma kapsamında, namus algısı ve namus cinayetleri hakkındaki anlayışlarının anlaşılması amacıyla seydalara; "Size göre namus nedir? Namus cinayetlerini nasıl değerlendiriyorsunuz? İslam ile namus cinayetleri arasında bir ilişki kurulabilir mi?" şeklinde sorular sorulmuştur. Bu sorulara seydaların verdiği cevaplardan, onların namus kavramına geniş bir anlam yelpazesi içinde yaklaştıkları anlaşılmaktadır. Seydalar, namus kavramının; genel olarak hem kadın hem de erkek cinselliği ve buna bağlı davranışları içermekle birlikte, bunları aşan anlamlara sahip olduğunu düşünmektedirler. Onlara göre namus, bir taraftan iffetini korumak, haram ilişkilerden uzak durmak, eşlerin birbirine sadakat göstermesi gibi cinsel bağlamlı, diğer taraftan toprağına ve malına sahip çıkmak, dinini, şeref ve haysiyetini korumak, akrabalarına sahip çıkmak, mazluma yardım etmek, yüz kızartıcı şeylerden uzak durmak, kanun ve nizamı tanımak, görevini ve mesleğini hakkıyla icra etmek gibi genel ahlak ilkelerini kapsayan geniş içerikli bir kavramdır. Aşağıdaki ifadeler seydaların, namus kavramını, medya aracllığıyla popülerleşen ve onu kadın cinselliğinden ibaret sayan anlayışlardan daha geniş bir perspektif ile değerlendirdikleri anlaşılmaktadır:

Namus; karı kocanın birbirine bağlılığıdır. Nikah var, birbirine bağlıdırlar... Birbirlerine karşı hak ve hukuklarına riayet etmektir. Namus müşterek bir şeydir. Aralarındaki o irtibattır. Allah adına birbirlerine verdikleri sözdür. Bekarlar için ise iffetini muhafaza etmektir, dindarlıktır yani bence. Bana göre namus kişinin dinine bağlılığı, helal ve haramlara riayet etmektir. Sadece hanımının veya bacısının şeyi [cinselliği] değil yani. (A. Kaymak: 60)

Seydaların tamamına yakını, namus adına işlenen cinayetleri katl olarak kabul etmekte ve kan davalarına yol açabilen bir fitne sebebi olarak görmektedir. Seydalara göre İslam'da gayrı meşru cinsel ilişkinin cezası, bekarlarda yüz değnek, evlilerde ise recmdir. Ancak had olarak bildirilen bu cezaların bireyler tarafından infaz edilmesi çok büyük toplumsal sorunlara yol açacağından, söz konusu cezalar mutlaka müesses nizam ve mahkeme mari-

n\%20T\%C3\%9CRK\%C4\%B0YE\%20RAPORU\%202\%20ve\%203.\%20d\%C3\%B6nem.pdf (Erişim: 26.11.2015).

55 Öztürk, Cahiliyeden İslamiyet'e Kadın, s.95. 
fetiyle infaz edilmelidir. Seydalardan biri bu yaklaşımı şöyle ifade etmektedir:

Şimdi İslam'da recm var mı? Var. Celde var mı? Var. Pislikte, dört şahidin şahitliği ile yani. Elbette cezai bir müeyyide uygulanacak yani. Yalnız bu cezanın uygulanmasının zaman ve zemini önemlidir. Evvela hududlar bir İslam devleti tarafından yapılmalıdır. O pisliği işleyenlerin ailesi tarafından öldürülmesi, bunun kesinlikle İslam'da yeri yoktur. Fertler yaparlarsa daha büyük felaketlere sebep oluyor. (Ș. Aslanlı: 55)

Seydalar namus cinayetlerinin İslam dini ile ilişkilendirilmesini doğru bulmamaktadırlar. Onlara göre bu cinayetlerin kaynağı din değil, toplumda yerleşik bulunan törelerdir. Seydalar, namus cinayetlerinde, şeyh veya seydalardan fetva alındığı iddialarını da şiddetle reddetmekte ve bu iddiaların şeyh ve seydaların toplumda itibarsızlaştırılması amacıyla kurgulandığını düşünmektedirler.

Görüşülen seydalardan üçü bazı durumlarda, zina suçu işleyen kimselerin, bireyler tarafından öldürülebileceğini ifade etmektedir. Onlara göre, örneğin kocanın, karısını başkaları ile zina ederken suçüstü yakalaması halinde veya devletin zina suçuna recm cezası vermemesi durumunda bireylere bu cezaları infaz yetkisi verilebilir. Ancak bu seydalardan sadece biri, kendisine başvurulması halinde bu yönde bir fetva verebileceğini ifade etmektedir.

\section{Sonuç}

Medreselerin temel dinî aktörleri olarak seydaların toplumsal cinsiyet algılarının başta hadis rivayetleri çerçevesinde fukahanın yorumları, ataerkil kültür ve Kur'an'ın toplumsal cinsiyetle ilgili değersel ve durumsal beyanlarının klasik tefsirlere yansıyan kadın imgesi ile oluştuğu söylenebilir. Bununla birlikte, modern dinî söylemler ve kentsel hayatın etkisi ile seydaların, kadının eğitimi ve ev dışında ücretli çalışması gibi konularda geleneksel anlayışlardan uzaklaştıkları anlaşılmaktadır.

Seydalar modernist dinî düşüncelere itirazlarını daha çok kadına ilişkin modern söylemler üzerinden yükseltmektedirler. Onlara göre kadının Batılı tarzda erkekle eşitliği anlamında 'özgürleşmesi', İslam dünyasında aile ve toplumun yozlaşmasının en temel nedenini oluşturmaktadır. Bu bağlamda seydaların bir 'modern kadın' endişesi yaşamakta oldukları söylenebilir.

Seydalar bir taraftan modernizmin kadın anlayışını eleştirirken diğer yandan namus cinayetleri ve kız çocuklarının küçük yaşta veya zorla evlendirilmesi gibi Müslüman toplumların kadına dair uygulamalarına da eleşti- 
rel yaklaşmaktadırlar. Bu durum onları, kadın konusunda eklektik ve apolojetik tutum takınmaya, söylem ve pratikler konusunda çelişkilere sevk etmektedir. Örneğin toplumsal cinsiyet konusunda seydalar söylemde modern ama pratikte muhafazakar eğilimli olabilmektedirler. İslam dünyasının modernleşme sürecinde, kadına bakışın değişmeye başlamasının beraberinde getirdiği düşünsel ve pratik düzlemdeki geçiş, çelişki ve gerilimlerin, dinî otoriteler olarak seydalarda eleştirel, savunmacı veya retçi yaklaşımlara neden olması ya da onların düşünce ve pratikleri arasında çelişki veya melez tutumlar ortaya çıkarması anlaşlabilir bir durumdur. Öte yandan seydaların toplumsal cinsiyet konusunda yaşadıkları çelişkilerde ilahi metin ile maddi dünyanın gerçeklikleri arasındaki gerilimlerin de önemli bir payı vardır.

Bireysel ve toplumsal değişim olgusu gerilimli süreçleri ifade eder. Geleneksel değerlerin aşınması ve modernleşme eğilimleri, bireylere yeniden kimliklenmeyi dayatır. Yeniden kimliklenme süreci, çoğunlukla eski ve yeni değerlerin birbirinin yerine geçmesi şeklinde değil, bu değerlerin birbirine eklemlenmesi ve karışması biçiminde işlemektedir ki bu durumda "karışım kimlikler" veya "melez desenler" ortaya çıkmaktadır. Bu olguya, seydaların toplumsal cinsiyet konusundaki, kadına yönelik şiddeti olumlayan tutumlarında olduğu gibi geleneksel ve kadının eğitimi konusundaki tutumlarında olduğu şekliyle modern anlayışları bir arada barındıran yaklaşımları tipik bir örnek oluşturmaktadır.

Aile dinsel duyarlılığın doruğa ulaştığı bir kurumdur. Bu itibarla İslam dünyasında modernleşmeye yönelik ilk tepkilerin kadına ve aileye yönelik düzenlemelerle ilgili olması doğaldır. Seydaların, toplumsal cinsiyet konusundaki ilgi ve hassasiyetleri de bu bağlamda anlaşılmalıdır.

Müslüman gelenekte ulemanın çoğunlukla nassa rağmen ve kadın karşıtı kültürel tutumların etkisiyle geliștirdikleri toplumsal cinsiyet algısının seydalarda derin bir kırılmaya uğramış olduğu söylenemez. Bu bağlamda modern İslam düşüncesinin, geleneksel cinsiyet statü ve rollerinin dönüşümüne yönelik teklifleri veya Diyanet İşleri Başkanlığının fetvalarında kadınlara yönelik açılımlarının seydalar üzerindeki yansımalarının da oldukça sınırlı olduğu anlaşılmaktadır.

Seydalar modern Batılı değerleri, İslam toplumlarının varlığını tehdit eden bir tehlike olarak görmekte ve bu değerler karşısında konumlandırdıkları Müslüman kimliğinin tanımlanmasında kadını fark arz eden bir unsur olarak kullanmaktadırlar. Bu anlayış paralelinde, İslam dininin yozlaştı- 
rılmasına yol açacak bir değişim süreci karşısında, öteden beri olduğu şekli ile kadın ve şer'i hukuk, birer emniyet bariyeri olarak görülmektedir.

Ontolojik olarak kadın-erkek arasında belirgin bir değer ayırımı yapmayan seydalar, cinsiyetler arasında kurumsallaşmış statü ve rol dağılımlarını ise, biyoloji ve fitrat gibi vurgularla işlevselci bir okuma ile ve bütün bunları son kertede ilahi iradeye bağlamak suretiyle meşrulaştırmaktadırlar. Birer dinî otorite olarak seydalar, toplumsal olarak kadın biyolojisine giydirilen çok boyutlu değer kisvelerinin kültürel arkaplanını göz ardı ederek, birçok yönüyle geleneksel toplumsal cinsiyet anlayışlarını meşrulaştırmakta ve bu anlayışların yeniden üretimine katkı sağlamaktadırlar.

\section{KAYNAKÇA}

Aḥmed b. Ḥanbel. el-Musned. Beyrut: el-Mektebu'l-İslāmī; Dāru Șādir, tsz.

Akkaya, Nejla. "İslâm Hukukunda Kadının Siyasi Hakları," İslâmî Araștırmalar 5:4 (1991), ss.236-250.

Alpago, Ceyda. "Kadına Yönelik Şiddet ve Kadın Sı̆̆ınma Evleri Olgusu," Yayınlanmamıs yüksek lisans tezi, İstanbul Üniversitesi, İstanbul, 2006.

Aslan, Esra. "Töre Cinayetleri: Diyarbakır'da Göç Sonrası Töre," Yayınlanmamış yüksek lisans tezi, Dicle Üniversitesi, Diyarbakır, 2007.

Aslan, Esra. "Din ve Şiddet Ekseninde Kadın Cinayetleri," Salih Öz ve Recep Vardi (ed.), Günümüz İslam Toplumları ve Problemleri Sempozyumu (İstanbul: Akademi Titiz Yayınları, 2015) içinde, ss.35-60.

Atalay, Orhan. 20. Yüzyıl Tefsir Akımı: İçtimâî Tefsir. İstanbul: Beyan Yayınları, 2004.

Ateș, Abdurrahman. Kur'an'a Göre Dinde Zorlama ve Şiddet Sorunu. İstanbul: Beyan Yayınlarl, 2002.

Ateş, Ali Osman. Hadis Temelli Kalıp Yargılarda Kadın. İstanbul: Beyan Yayınları, 2000.

Aydınalp, Halil. "Türkiye'de Dinî Yapı: Örnek Alanlar Üzerinden Bir Tasvir," Hayati Hökelekli (ed.), Dindarllk Olgusu: Sempozyum Tebliğ ve Müzakereleri (Bursa: Kurav Yayınları, 2006) içinde, ss.301-318.

Aysoy, Mehmet. Gelenek Sonrası Toplum Üzerine. İstanbul: Açı Kitaplar, 2003.

Azimli, Mehmet. "Kadınların Yöneticiliği Konusundaki Rivayete Tarihsel Bağlamda Eleștirel Bir Yaklaşım," İslâmî Araştırmalar 15:3 (2002), ss.417-422.

Azimli, Mehmet. Siyeri Farklı Okumak: Medine Yılları. Ankara: Ankara Okulu Yayınları, 2009.

Baktır, Mustafa. "İslam'da Kadının Çalışma Şartları," Sosyal Hayatta Kadın, 3. bsk. (İstanbul: Ensar Neşriyat, 2005) içinde, ss.120-148.

Berkes, Niyazi. Türkiye'de Çağdaşlaşma. 6. bsk. İstanbul: Yapı Kredi Yayınları, 2004.

Berktay, Fatmagül. Tektanrılı Dinler Karșısında Kadın: Hıristiyanlık'ta ve İslamiyet'te Kadının Statüsüne Karşılaştırmalı Bir Yaklaşım. 3. bsk. İstanbul: Metis Yayınları, 2009. 
Bilgin, Vejdi. Fakih ve Toplum: Osmanlı'da Sosyal Yapı ve Fıkıh. İstanbul: İz Yayıncllık, 2003.

Birleşmiş Milletler CEDAW Komitesine Sunulmak Üzere Hazırlanan İkinci ve Üçüncü Birleştirilmiş Periyodik Türkiye Raporu, Ankara: 2003. https://www.tbmm.gov.tr/komisyon/kefe/belge/uluslararasibelgeler/ayr imci-

lik/CEDAW/ulke_raporlari/CEDAW\%20Komitesi'ne\%20verilen\%20T\%C3 \%9CRK\%C4\%B0YE\%20RAPORU\%202\%20ve\%203.\%20d\%C3\%B6nem.p df (Erişim: 26. 11. 2015)

Charney, Jean-Paul. İslâm Kültürü ve Toplumsal Ekonomik Değişim. Terc. Adnan Bülent Baloğlu, Osman Bilen. Ankara: TDV Yayınları, 1997.

Çapçığlu, İhsan. Modernleșen Türkiye'de Din ve Toplum. Ankara: Otto Yayınları, 2011.

Dikeçligil, Beylü. "Kültür Kavramının Analizi veya Sosyo-Kültürel Gerçekliğin Yapısı Üzerine Bir İnceleme," Köksal Alver, Necmettin Doğan (ed.), Kültür Sosyolojisi, 3. bsk. (Ankara: Hece Yayınları, 2013) içinde, ss.133-150.

Erdoğan, Mehmet. "Kadın Hakları Bağlamında Boşanma Sorunu," Rahmi Yaran ve Abdurrahman Dodurgalı (yay. haz.), İslam Düşüncesinde Yeni Arayışlar III (İstanbul: Rağbet Yayınları, 2000) içinde, ss.138-149.

Erkan, Rüstem. Güneydoğu Anadolu Bölgesinin Sosyal Yapısı ve Değişme Eğilimleri. Ankara: Kalan Yayınları, 2005.

Erkan, Rüstem ve Faruk Bozgöz. "Kadına Yönelik Şiddetin Sosyo-Ekonomik, Dinsel ve Kültürel Boyutları: Diyarbakır Örneği," EKEV Akademi Dergisi 8:18 (2004), ss.219-242.

Gençoğlu Onbaşı, Funda. ''Geleneksel' ve 'Modern': Sınırlar ve Geçirgenlikler Üzerine," Doğu Batı 7:25 (2003), ss.83-98.

Giddens, Anthony ve Philip W Sutton. Sosyolojide Temel Kavramlar. Çev. Ali Esgin. Ankara: Phoenix Yayınları, 2016.

Giddens, Anthony. Modernliğin Sonuçları. Çev. Ersin Kuşdil. 6. bsk. İstanbul: Ayrıntı Yayınları, 2014.

Göle, Nilüfer. Seküler ve Dinsel: Aşınan Sinırlar. Çev. Erkan Ünal. İstanbul: Metis Yayınları, 2012.

Gusfield, Joseph R. "Toplumsal Değişim Araştırmalarında Yersiz Kutuplaşma: Gelenek ve Modernite," çev. Bilal Canatan, Muhafazakar Düşünce 1:3 (2005), ss.55-72.

Hamidullah, Muhammed. Aziz Kur'ân. Terc. Abdülaziz Hatip ve Mahmut Kanık. İstanbul: Beyan Yayınları, 2003.

Hassan, Riaz. Müslüman Zihinler. Çev. Ergin Çenebaşı. İstanbul: Doğan Kitap, 2010.

Hatemi, Hüseyin. Kadının Çıkış Yolu: İlâhî Hikmet'de Kadın. İstanbul: İşaret Yayınları, 1990.

İkbal, Muhammed. İslam'da Dinî Düşüncenin Yeniden İnşâsı. Çev. Rahim Acar. 1. bsk. İstanbul: Timaş Yayınları, 2013.

Jansen, Henrica A. F. M. ve diğerleri. Türkiye'de Kadına Yönelik Aile İçi Şiddet. Ankara: T.C. Başbakanlık Kadının Statüsü Genel Müdürlüğ̈̈, 2009. 
Kahraman, Bayram. "Diyarbakır'ın Toplumsal Yapısı ve Diyarbakır Halkının Toplumsal Kurumlara Bakışı," Yayınlanmamış yüksek lisans tezi, Sakarya Üniversitesi, Sakarya, 2014.

Kara, İsmail. Şeyhefendinin Rüyasındaki Türkiye. İstanbul: Dergâh Yayınları, 2011.

Karaman, Hayreddin. "Kadının Şahitliği, Örtünmesi ve Kamu Görevi," İslâmî Araştırmalar 5:4 (1991), ss.284-291.

Karaman, Hayreddin. İslam'ın Işığında Günün Meseleleri. İstanbul: Nesil Yayınları, 1992.

Karaman, Hayreddin. Íslam'da Kadın ve Aile. İstanbul: Ensar Neşriyat, 1993.

Merad, Ali. Çağdaş İslam. Çev. Cüneyt Akalın. İstanbul: İletişim Yayınları, tsz.

Muslim b. el-Ḥaccāc en-Nīsābūrī. Ṣaḥịhu Muslim. 3. bsk. Beyrut: Dāru'l-Márife, 2010.

Oğuz, Hayrettin. "Postmodern Bir Süreçte, Postmodern Bir Darbe ve Postmodern İslamcılık," Gelenek ve Modernlik Arasında İslâmcılık (İstanbul: Umran, 2013) içinde, ss.261-268.

Okuyan, Mehmet. "Kadına Yönelik Şiddete Kur'ân'ın Bakıșı,” Ondokuz Mayıs Üniversitesi İlahiyat Fakültesi Dergisi 23 (2007), ss.93-134.

Özdeş, Talip. "İslam Açısından Kadının Konumu ve Kadına Yönelik Şiddetin Değerlendirilmesi," Eskiyeni 12 (2009), ss.68-76.

Öztürk, Mustafa. Cahiliyeden İslamiyet'e Kadın. Ankara: Ankara Okulu Yayınları, 2012.

Sarmıș, İbrahim. Rivayet Kültürü ve Olumsuz Kadın Algısı. 2. bsk. İstanbul: Düşün Yayınları, 2011.

Savaş, Rıza. Hz. Muhammed (sav) Devrinde Kadın. 3. bsk. İstanbul: Ravza Yayınları, tsz.

Shayegan, Daryush. Melez Bilinç. Çev. Haldun Bayrı. 2. bsk. İstanbul: Metis Yayınları, 2014.

Sıddıkî, Mazharuddin. İslâm Dünyasında Modernist Düşünce. Çev. Murat Fırat, Göksel Korkmaz. İstanbul: Dergâh Yayınları, 1990.

Şefkatli Tuksal, Hidayet. Kadın Karşıtı Söylemin İslam Geleneğindeki İzdüşümleri. Ankara: Kitâbiyât, 2000.

Şimşek, M. Said. Günümüz Tefsir Problemleri. Konya: Esra Yayınları, 1995.

Vedûd-Muhsin, Amine. Kur'ân ve Kadın. Çev. Nazife Şişman. 3. bsk. İstanbul: İz Yayıncılık, 2005.

Yalar Mehmet. "Seyda, Mela ve Feqilerin Bölgenin Dini ve Kültürel Hayatındaki Yeri," Fikret Gedikli (ed.), Medrese Geleneği ve Modernleşme Sürecinde Medreseler (Muş: M. Ş. Ü. Yayınları, 2013) içinde, c.1, ss.459-470.

Yapıcı, Asım ve Münir Yıldırım. "Küreselleşme Sürecinin Dinî Kimliklere Etkisi: Sosyal Psikolojik Bir Değerlendirme," Dinî Araştırmalar 6:17 (2003), ss.117-138.

Yazır, Elmalılı M. Hamdi. Hak Dini Kur'an Dili. İstanbul: Zehraveyn Yayınları, tsz. 